\title{
Medical error and negligence as a premise of liability for damage caused to patients
}

\author{
Piotr Stępniak
}

Poznan University of Medical Sciences, Poznan, Poland

\begin{abstract}
This article is devoted to the problem of compensation of damage caused to patients by medical personnel in connection with the provision of health services. It considers 2 situations: medical error and negligence? In legal construction of compensation for medical errors are caution and due diligence in action. The article analyses both concepts. It also refers to negligence in connection with the provision of health services. The development of medicine, respect for ethical standards, as well as patient rights, mean that the tendency towards and highest diligence when providing medical services is becoming more pronounced.

The article emphasizes that a similar position is taken by the Court in Poland. The duty of due diligence results from the professional nature of the doctor's actions. It is defined by the medical standards. In the author's opinion, the concept of due diligence and caution in action can be used both for the assessment of medical error and for medical care characterized by negligence.
\end{abstract}

KEY WORDS: medical errors, damage, compensation, diligence, negligence, medical personnel.

ADDRESS FOR CORRESPONDENCE: Piotr Stępniak, Chair and Department of Medical and Pharmaceutical Law, Poznan University od Medical Sciences, Poland, e-mail: pstepniak@ump.edu.pl, prawo@ump.edu.pl

\section{INTRODUCTION}

The article deals with selected legal problems related to compensation for damages arising from the provision of health services, focussing only on tort, i.e. the tort of a person providing such services, especially a doctor or a nurse. The thesis discussed in the text is that the grounds for such liability may be two-fold; namely, medical error or negligence on the part of medical staff in the provision of health services. Although they are listed separately in the doctrine of medical law in Poland, it is assumed herein that in medical practice they often overlap. The issue therefore being considered in the text is also the extent to which the courts perceive this in cases of compensation for the damage caused to patients.

\section{GENERAL REMARKS ON THE LEGAL} EDUCATION OF PATIENTS AND MEDICAL STAFF

The number of health services provided is increasing significantly from year to year. There is also a clear increase in patients' legal awareness, resulting in an increasing number of claims on their part [1]. These claims are related to the liability of medical personnel for damage caused to patients.

The issue outlined above is therefore constantly gaining in importance. The increasing knowledge of medical law among patients is forcing the need for legal education also for medical personnel. Therefore, this article fits into this perspective and is intended for people practicing the medical profession, especially for doctors and nurses. The latter are most at risk of causing injury or harm to the patient. This is connected, on the one hand, with easier access to health services provided by them and to more and more numerous examinations and specialist treatments, and on the other, to the medical regulations governing them. The Internet in particular plays a major role in raising legal awareness in patients.

In my observation as a professional lawyer indicated factors, as well as the increasingly widespread use of legal counselling and assistance by patients, mean that medical personnel should also be sensitive to various legal aspects of their professional functioning. 


\section{MEDICAL ERROR AND NEGLIGENCE IN PROVIDING HEALTH SERVICES IN THE LEGAL ASPECT}

This functioning of medical staff, like every human action, is associated with various threats and risks. This is also the case with the provision of health services. One such risk is that of making a medical error or negligence in providing health services. The analysis of the legal aspect of this issue requires recalling the definition of a medical service. Error and neglect occur because of it or in connection with it.

Taking the issues raised, it is worth starting with the statutory and thus legal definition of health services. Thus, according to art. 2 item 1 point 10 of the Act of 15 April 2011 on medical activity [Journal of Law 2011, no. 112, pos. 654], these are actions aimed at preserving, saving, restoring, or improving health, and other medical activities resulting from the treatment process or separate provisions regulating the principles of their performance. These actions are taken by medical staff. This concept relativizes, in the institutional dimension, a group of people practicing various medical professions entitled to provide health services, as well as persons with professional qualifications, to provide health services in a specific scope or in a specific field of medicine (cf. article 2 item 1 point 2 of the Act on medical activity).

In view of the above, it should be noted that the notion of medical error is not the same as the notion of medical malpractice, although it is often used interchangeably in everyday language. The first one of these is broader in scope because as it also applies to non-doctors. However, the position sometimes presented in the literature, that organizational, technical errors, etc. associated with the movement of medicinal entities are also medical errors, does not seem accurate $[2,3]$. These are rather defects that cause its malfunction, resulting from human error at one of the stages of organization and management of this activity.

M. Nesterowicz associates them with the so-called "organizational fault". According to him, this concept means improper organization of the medical entity, visible in the absence of appropriate medical staff, insufficient qualifications, inadequate conditions of surgery or treatment, and finally faulty organization of the treatment process [4].

In the above sense, the term "medical error" can therefore be defined as any behaviour of a person providing health services objectively contrary to generally recognized precautionary principles. It also covers medical malpractice, which depends primarily on the current state of knowledge in the field of medicine.

However, it is worth noting that the doctor or nurse is liable for damage caused to the patient only when the error was at fault [5]. This is called tort liability, i.e. for a tort (cf. Art. 415 of the Civil Code). According to the doctrine of civil law, it should be assumed that the fault occurs when a doctor, nurse, or other person performing a medical profession may be accused of objective and subjective inappropriate behaviour [5]. An objective element of guilt is the so-called illegality, i.e. the contradiction of their acts or omissions with the entire legal order, with a specific provision, with the principles of social coexistence or other norms commonly used and accepted in a given society (e.g. rules of medical procedure).

The subjective element of guilt, apart from sanity, also concerns the relationship of the acting medic's will and awareness of his/her act. The blame can therefore be assigned to a specific doctor, nurse, etc. only if there are grounds for a negative assessment of his/her behaviour from the point of view of both these conditions $[6,7]$.

It follows from the foregoing considerations that the concept of medical error may intersect with the concept of lack of diligence. In some cases, the error may also result from it. For example, this happens in situations where the deviation from the medical procedure occurs due to a lack of all the necessary surgical instruments, a lack of suitable dressings, medicines, etc.

\section{CAUTION AND DUE DILIGENCE IN ACTION AS KEY CONCEPTS IN COMPENSATION FOR MEDICAL ERRORS}

The key concepts in compensation for medical errors are therefore precaution, and more strictly standardized rules and due diligence in action. However, they can also be referred to the concept of negligence during and in connection with the provision of health services. Therefore, the directives arising from them require that the person providing health services should have the appropriate qualifications to perform a given activity and carry out this activity using the appropriate apparatus or tool, and also to carry it out in accordance with the adopted medical procedure, i.e. in an appropriate, standardized manner.

Therefore, the issue of precaution is connected with the issue of diligence in providing health services, whereby it is important to adopt the term "due" as a measure of this diligence, as well as to relativize it to given medical circumstances (e.g. surgery). It is worth considering whether the definition of due diligence in art. $355 \$ 1$ of the Civil Code is adequate to this.

Analysing the issue mentioned above, it should be noted that it has been the subject of many courts' decisions. However, such decisions usually concern variable relations, analysed in the context of a constantly changing economic reality. It turns out that the assessment of due diligence according to the criteria of art. $355 \$ 1$ of the Civil Code is quite difficult. Nevertheless, several interpretative guidelines for this regulation can be found in judicial decisions.

Thus, in principle, due diligence should be understood as the diligence generally required in a given relationship. Its pattern is therefore objective. Its reference 
to practice, in turn, requires the optimal procedure to be determined for the given conditions, and then the debtor's behaviour to be compared with it. This method should be appropriately standardized and socially approved. It can be assumed that a person providing medical services is a debtor in the sense that there is a relationship resulting from an obligation between him/her and the patient on the basis of which he/she provides these services. Not only the incompatibility of their behaviour with the established model, but also the possibility and obligation to anticipate appropriate consequences of behaviour, determined by life experience, decided whether they can be accused of lack of due diligence in fulfilling their duties when analysing specific circumstances.

However, the assessment of due precaution cannot be formulated taking into account non-enforceable obligations, detached from experience, professional rules, specific circumstances, or type of relations (cf. judgements of the Supreme Court of 17 May 2002, I CKN 1180/99, LEX No. 1172 457, of 23 October 2003, V CK 311/02, LEX No. 82 272, of 8 July 1998, III CKN 574/97, LEX No. 462 941).

\section{STANDARDS AND CRITERIA OF DUE DILIGENCE IN THE PROVISION OF HEALTH SERVICES}

If the above general remarks are transferred to the field of medical law, it should be noted that legal medical relations constitute a special type of relationship. The circumstances related to the provision of health services are also special. This raises the question of whether the criterion for assessing due diligence according to general rules is sufficient here, or whether it should be qualified for medical relations, i.e. the highest diligence possible in a particular situation (e.g. during surgery).

The author of the article does not share the view previously expressed by the part of the doctrine that due diligence in medical situations means maintaining attention and sufficient accuracy [6]. Medical staff, in particular doctors, exercise the profession of public trust. They also play a special role in society. The highest good, which is human life and health, as well as the fate of patients, depend on their activities, decisions, knowledge, and skills [6]. Legal responsibility cannot, therefore, be simply responsability of medical personel. The consequences of undesirable actions or omissions of medical staff can be incomparably more severe for patients than, e.g. defective performance of a contract of sale [8].

Consequently, the civil liability of medical staff must take into account the specific situations and circumstances related to the provision of health services [9]. This context includes, for example, rules that determine whether medical personnel have exercised due diligence or whether should be taken into account (rules) must take into account the conditions under which they acted, and whether they may have acted in accordance with the precautionary principles and current medical knowledge under those conditions.

The development of medicine, respect for ethical standards in the provision of health services, as well as the patients' rights, mean that the tendency towards the standard of special care, and therefore the highest care in the provision of medical services, is becoming more pronounced. Highly specialized health services (e.g. in the field of electroradiology and some dental procedures) can now be treated as requiring just such precautions and diligence, and it is important that they are possible to achieve under the given treatment conditions.

The Supreme Court also holds a similar position. In determining due diligence, it pointed to the professional nature of the activities of medical doctors. Due to this, their diligence should be particularly high, as defined by the professional's standard. In a judgment of 29 October 2003, the Supreme Court therefore held that the doctors should carry out surgical procedures in accordance with the art of medicine and medical science and the utmost care required of a professional [10].

From the point of view of this article, it is important that the above-mentioned concept of due diligence, as well as precaution in action, can be used both for the assessment of medical error and medical conduct characterized by negligence. This conclusion is worth developing.

When analysing the relationship between a breach of precautionary rules and medical error, it should be asked whether this behaviour is contrary to a specific, general pattern of conduct in medicinal entities, in particular medical or paramedical procedures (e.g. administration of drugs and temperature measurement at specific times), or appropriate for a specific situation, i.e. individualized. In the author's opinion, it is possible to determine whether there has been a medical error only in specific, individualized medical circumstances (e.g. during surgery or radiation). This results in the recognition that a breach of precautionary rules in the provision of health services could only occur in such circumstances. This determines the modal nature of the concept of caution, because it must be related to the requirements imposed by them. In hospital settings, they will be differentiated in terms of their character. Different caution is required when placing a peripheral venous catheter while in a patient's room and different during open-heart surgery while in the operating block.

In the light of the above, it is not difficult to distinguish between a medical error and negligence in the provision of health services. It should be noted that the literature on the subject and judicial decisions most commonly suggest within the limits of medical error, there are only situations in which the incorrect conduct of medical staff (e.g. doctors) is due to failure to comply with the rules of "medical science", "knowledge and the art of medicine", or "medical knowledge and practice" 
[11-13]. Failure to comply with such rules always means a qualified lack of caution, i.e. gross-negligence, whether it refers to non-compliance with medical procedures, directives resulting from medical experience and practice (medical errors), or hasty action, without concern for its accuracy and reliability (negligence).

M. Nestorowicz and K. Bączyk-Rozwadowska, rightly stated that cases of medical errors do not include cases of non-compliance by medical staff, including doctors, with the applicable rules of professional conduct, infringement of which may be identified without reference to expertise (e.g. leaving a foreign body in the operating field) $[3,14]$. However, they can be classified as negligence. It is the opposite of diligence. It means either not taking specific actions or activities by disregarding their meaning, or performing a task carelessly, without due attention to accuracy, reliability, or compliance with possible requirements (legal, technical, formal, etc.).

Negligence is always reprehensible. It can also manifest itself in the in action required by medical knowledge [15]. As such, it qualifies for tort (cf. Book 3, Title VI of the Civil Code).

\section{DIFFERENCES BETWEEN MEDICAL ERROR AND NEGLIGENCE INDICATED IN THE JUDGMENTS OF THE COURTS}

In order to better illustrate the differences between medical error and negligence in the provision of health services, it is worth giving a few examples.

As a preliminary point, however, it should be noted that the analysis of court records in cases of compensation for medical errors committed by doctors leads to the conclusion that actions are based, as a rule, on the the legal construction of a therapeutic error. It is therefore worth recalling that both medical and legal literature indicates that a therapeutic error occurs in the following cases:

- choosing the wrong method or a defective treatment method (e.g. prescribe the wrong or not being informed about its use),

- an improperly carried out operation,

- extending the operating field without need and necessity,

- acting contrary to recognized principles of medical knowledge or manifestly in breach of generally proven rules of medical procedure where, from an objective point of view, such an error should not be made by the doctor.

However, the legal principle is that a doctor's liability for harm caused to a patient may be the result of culpable error. A medical error as acting contrary to recognized principles of medical knowledge fulfils an objective element of guilt [16].

The following situation was examined in one of the cases before the Regional Court in Poznań.

The plaintiff (patient) indicated that on 8 June 2001 he underwent surgery to remove a right-sided inguinal hernia in the General and Traumatology Surgery Department of one of the hospitals in Poznan. The plaintiff was in this hospital from 5 June 2001 to 15 June 2001. Before the surgery, he had no complaints related to the presence of Staphylococcus aureus bacteria in his body. One week after the surgery, the postoperative control revealed that the wound was bleeding and festering. As a result, the patient was forced to visit the Surgery Outpatient Clinic for about 2 months. There, however, he was assured that his situation was typical and that the wound would heal in the near future. After this period, the wound significantly diminished, but there was still a purulent hole. It was not until 6 October 2004, at the patient's request, that a wound was performed. As a result, it was determined that there was an infection with Staphylococcus aureus. Further pharmacological treatment did not lead to the expected results, among others due to late diagnosis of infection. Finally, on 23 March 2006, the mesh was removed after previous surgery for inguinal hernia by another procedure with the diagnosis of "purulent fistula in the scar after right-sided inguinal hernia surgery".

In the above case, the court found that the doctors had committed a so-called therapeutic error. The court's assessment was justified by the fact that the patient was infected with Staphylococcus aureus in the hospital, as the experts ruled out that he had become infected during previous procedures due to the 30 -day period of appearance of the first symptoms. No antibiotics were given to the patient on the day of the procedure, which is a common practice precisely to avoid infecting or at least reducing the risk of such infection. The first signs of infection occurred as early as 3 days after being discharged from the hospital, but the hospital's medical staff refused to take a swab from the wound to determine the causes of suppuration, so it was groundless to assume that such symptoms are a normal result of the operation.

However, in the situation reconstructed by the court there was also serious neglect, which was characterized by gross negligence. This situation is indeed quite typical for various medical events, in which medical errors are accompanied by negligence, visible in the activities of medical staff.

The appearance of purulence in the wound and problems with its healing should be a signal to carry out tests in order to clarify the causes of such a patient condition. However, this did not happen. The defendant hospital staff grossly omitted such activities, exposing the patient not only to suffering but also to a life-threatening situation in the event that there was an infection of other organs. The swab from the plaintiff's wound was taken almost 5 years after the first symptoms of Staphylococcus aureus infection occurred. The source of infection due to the ineffectiveness of antibiotic therapy was eliminated only with the next surgery to remove a previously attached mesh.

According to the consistent line of judicial decisions, it is therefore necessary to distinguish between medical 
error and proceedings which have the characteristics of negligence. A typical example of it is leaving various surgical instruments or dressings in the patient's body after surgery. For example, the Supreme Court in 1967 judged that leaving a gas compress after surgery in the abdominal cavity, resulting in the patient's death, was gross negligence on the part of the attending doctor. Therefore, the court attributed to him not only deficiencies in medical knowledge, but also organizational negligence and lack of control over the work of the entire operational team [17].

Thirty years later, the Court of Appeal in Lublin took a similar position. In a judgment of 2 December 1999 , the Court ordered compensation for harm to a patient because of leaving surgical pliers in the abdominal cavity, $17 \mathrm{~cm}$ long and $8 \mathrm{~cm}$ wide, after gallbladder excision. This was the cause of long-term pain, which successive doctors diagnosed as a result of kidney, liver, pancreas, and heart disease. Her treatment was unsuccessful. The presence of pliers was shown only by an X-ray, taken after 6 years at the initiative of the patient, and therefore privately [18].

More examples could be given, but there is no place for it. Thus, it is sufficient to state that leaving a foreign body in the patient's body, in cases of compensation for defective provision of health services, is not treated by common courts as a medical error, but simply negligence. Its determination usually prejudges the doctor's guilt, and therefore of liability in tort, i.e. for tort, in relation to which the patient was injured or hurt. In this case, the operating person's guilt can be questioned only on the basis of the existence of extraordinary circumstances, the occurrence of which must, however, be proven (Article 6 of the Civil Code "the burden of proving a fact lies with the person who derives legal effects from this fact"). An example of this can be surgery in difficult conditions outside the hospital.

Negligence in the course of surgical operations is particularly outrageously negligent. Its perpetrators are doctors who can be required not only to exercise due diligence in the general meaning of the Civil Code (cf. Article $355 \S 1$ of the Civil Code), but qualified, and therefore highest, diligence.

However, examples of cases involving other people practicing the medical profession may also be given. Analysis of court records shows that there are often mistakes in the administration of medicines by nurses in hospitals. A typical example of negligence are also cases of violation of elementary principles of maintaining cleanliness and asepsis by medical analysts, physiotherapists, or electro-radiologists, or hospital infections of patients by hepatitis virus. In one of the cases heard by the Court of Appeal in Poznan, it was stated that in the hospital it was impossible to give serum to a patient who was bitten by a dog because the nurse lost the key to the medicine cabinet [19].
The examples mentioned above thus show that several other precautionary rules applicable to medical staff in the daily provision of health services remain outside the limits of medical error. Failure to respect these rules often has similar effects as failure to comply with the indications of current medical knowledge. As a consequence, it may affect the occurrence of liability in tort, i.e. for tort. Any situation relating to the provision of health services may cause damage or harm to the patient if it violates the precautionary rules. It is not relevant whether they concern a generally established caution, e.g. maintenance of cleanliness, or sepsis in a hospital, or special caution required, e.g. during surgery. In other words, a violation of the caution principles can fulfil the attributes of a medical error if it is manifested with disregard for the rigor of the medical procedure, or negligence, if it means unreliable, any or chaotic action.

\section{CONCLUSIONS}

Summarizing everything that has been said in this article about medical error and negligence, it is worth drawing some final conclusions.

There are 2 important premises for tort liability for damage caused to patients by the personnel providing the services. The first is medical error, i.e. proceedings contrary to the current state and principles of medical knowledge. The second is lack of due diligence, i.e. negligence related to violation of the rules of conduct of medical entities and the principles of their functioning.

In the practice of providing health services, medical error is most often associated with neglect. Both are related to a violation by a doctor or nurse of the precautionary rules. Error occurs when they have neglected the rigor of medical treatment, and negligence if their actions have been careless or chaotic.

For these reasons, the ordinary courts in their practice of judicating do not clearly separate medical error from negligence. This is demonstrated by the analysis of the judgments indicated in the text.

However, the judgments indicated in the text show that in the practice of providing health services, violation of the precautionary principles applicable to medical personnel remains beyond the limits of medical error or even negligence.

There is therefore no connection with the strictly medical procedure. In such situations, however, the effects may be similar to non-compliance with the indications of current medical knowledge. These rules can therefore be breached not only by doctors, nurses, or other medical professionals, but also by employees of medical entities, e.g. support staff, service personnel, etc.

\section{DISCLOSURE}

The author declares no conflicts of interest. 


\section{References}

1. Rzecznik Praw Pacjenta zasypany skargami. Najgorzej na Mazowszu, Śląsku i Wielkopolsce [The Patient Ombudsman inundatet with complaints. The worts in Mazovia, Silesia and Greater Poland]. Available from: https://www.rynekzdrowia. pl/Polityka-zdrowotna/Rzecznik-Praw-Pacjenta-zasypany-skargami-Najgorzej-na-Mazowszu-Slasku-i-Wielkopolsce,224002,14.html (accessed: 11 April 2021).

2. Szostak R, Kozak M. Odpowiedzialność karna za błędy w sztuce medycznej [Criminal liability for errors in medical art]. Studia prawno-ustrojowe 2014; 25: 120-127.

3. Kis-Wojciechowska M, Przybylski Z. Błąd medyczny [Medical error]. Homines Hominibus 2011; 7: 139.

4. Nesterowicz M. Prawo medyczne [Medical law]. TNOiK, Toruń 2013; X: 338.

5. Sośniak M. Cywilna odpowiedzialność lekarza [The doctor's civil liability]. Wydawnictwo Prawnicze, Warszawa 1989.

6. Serwach M. Wina jako zasada odpowiedzialności cywilnej oraz okoliczność zwalniająca z obowiązku naprawienia szkody [Fault as a principle of civil liability and a circumstance exempting from the obligation to compensate for damage]. Wiadomości ubezpieczeniowe 2009. Available from: https://www.piu.org. pl/.../WU1_09_serwach_84-96.pdf ·(accessed: 11 April 2021).

7. Serwach M. Ubezpieczenia odpowiedzialności cywilnej lekarza [Physician's liability insurance]. Med Prakt 2016; 2: 111.

8. Brykczyński J. Odpowiedzialność cywilna lekarza i podmiotu leczniczego za szkodę medyczną [Civil liability of the doctor and the medical entity for medical damage]. Wydawnictwo Termedia, Poznań 2013.

9. Klich A. Paternalizm czy współodpowiedzialność? Stosunek lekarz-pacjent a zgoda pacjenta na zabieg medyczny w polskim porządku prawnym [Paternalism or shared responsibility? The doctor-patient relationship and the patient's consent to a medical procedure in the Polish legal order]. Available from: http:// www.prawoimedycyna.pl/index.php? str=artykul\&id=1031 (accessed: 11 April 2021).

10. The Supreme Court, the judgement of 26 september $2003 \mathrm{r}$., case IV CK 32/02. Available from: https://sip.lex.pl/orzeczenia-i-pisma-urzedowe/orzeczenia-sadow/iii-ck-34-02-wyroksadu-najwyzszego-52023892 (accessed: 11 April 2021).

11. Biesaga T. Autonomia lekarza i pacjenta a cel medycyny [The autonomy of the doctor and the patient and the goal of medicine]. Med Prakt 2005; 3: 20-24.

12. Dziedziczak W. Próba charakterystyki sankcji prawnych i moralnych [An attempt to characterize legal and moral sanctions]. Annales UMCS 1992; XXXIX: 34.

13. Lewicki M. Pojęcie sankcji prawnej w prawie administracyjnym [The concept of a legal sanction in administrative law]. Państwo i Prawo 2002; 8: 64.

14. Bączyk-Rozwadowska K. Odpowiedzialność cywilna za szkody wyrządzone przy leczeniu [Civil liability for damages caused during medical treatment]. TNOiK, Toruń 2007.

15. Liszewska A. Wątpliwości wokół pojęcia błędu w sztuce lekarskiej [Doubts around the concept of medical malpractice]. Acta Universitatis Lodziensis. Folia Iuridica 1994; 60: 132.
16. Sroka T. Odpowiedzialność karna za niewłaściwe leczenie [Criminal responsibility for improper treatment]. Wydawnictwo Wolters Kluwer, Warszawa 2013.

17. The Supreme Court, the judgment of 2 March 1967. II Cr 435/67, publ. OSN 1968, poz. 136.

18. Court of Appeal of Lublin, the judgement of 2 December 1999. Sign. I Ca 412/99, publ. OSA 2/1999, poz. 12.

19. Portal Orzeczeń [Judgement Portal]. Available from: https:// poznan.sa.gov.pl portal-orzeczen,mg,174,180 (accessed: 11 April 2021). 